\title{
Enterococcus thailandicus sp. nov., isolated from fermented sausage ('mum') in Thailand
}

Correspondence

Somboon Tanasupawat

Somboon.T@chula.ac.th

\section{Somboon Tanasupawat, ${ }^{1}$ Sirapan Sukontasing ${ }^{1}$ and Jung-Sook Lee ${ }^{2}$}

\author{
${ }^{1}$ Department of Microbiology, Faculty of Pharmaceutical Sciences, Chulalongkorn University, \\ Bangkok 10330, Thailand \\ ${ }^{2}$ Korean Collection for Type Cultures (KCTC), Biological Resource Center, Korea Research Institute \\ of Bioscience and Biotechnology (KRIBB), 52 Eoeun-dong, Yuseong-gu, Daejeon 305-333, \\ Republic of Korea
}

Enterococci have been isolated from plants, soil, animals, humans and raw and prepared food including meat, poultry, fish, egg, milk, cheese and vegetables and traditional fermented foods (Knudtson \& Hartman, 1992; Sukontasing et al., 2007). The classification of the genus Enterococcus has undergone considerable changes as a consequence of the increase in the number of novel species and also improvements in the methods used to discriminate separate species (Baele et al., 2000; Merquior et al., 1994; Naser et al., 2005). At the time of writing, 34 Enterococcus species names have been validly published (Euzéby, 1997; last full update May 14, 2008). Several species groups, Enterococcus faecium, E. avium, E. gallinarum, E. cecorum, E. faecalis and other species groups, including E. saccharolyticus, E. sulfureus and E. dispar, were revealed based on comparative 16S rRNA gene sequence analysis (Hardie \& Whiley, 1997; Švec et al., 2006). Here we describe a novel bacterium, strain $\mathrm{FP} 48-3^{\mathrm{T}}$, isolated from fermented sausage ('mum'), and propose that it represents

The GenBank/EMBL/DDBJ accession numbers for the 16S rRNA and rpoA gene sequences of strain $\mathrm{FP}_{48}-3^{\top}$ are EF197994 and EU015878, respectively.

Neighbour-joining phylogenetic trees, based on $16 \mathrm{~S}$ rRNA and rpoA gene sequences, showing the relationships between strain FP48-3 ${ }^{\top}$ and related species are available as supplementary material with the online version of this paper. a novel species, based on phenotypic and chemotaxonomic characteristics, DNA-DNA relatedness and 16S rRNA and RNA polymerase $\alpha$-subunit ( $r p o A)$ gene sequence analysis.

Samples of fermented sausage were collected from Khonkaen province, north-eastern Thailand. Cocci arranged in chains were isolated from the samples using GYP-CaCO ${ }_{3}$ agar (Tanasupawat et al., 1992). Cultures grown using GYP-sodium acetate-mineral salt broth (Tanasupawat et al., 1992), adjusted to $\mathrm{pH} 7.2$, were used for working cultures. All tests were performed by incubating the cultures at $30^{\circ} \mathrm{C}$. Cell shape, size, arrangement and colony appearance were examined using cells grown on GYP agar for 3 days. Gram staining was done as described by Hucker \& Conn (1923). Spore formation was examined using the Gram-stained specimen. Results of the oxidation-fermentation test and motility were examined in soft agar (Whittenbury, 1963). Catalase activity, hydrolysis of gelatin, aesculin, arginine and starch, nitrate reduction, production of gas from glucose, gluconate and citrate, and acid formation from carbohydrates were tested as reported by Tanasupawat et al. (1992). Additional biochemical characteristics were recorded after 2 days incubation in API $50 \mathrm{CH}$ strips. Hydrolysis of horse blood was assessed as described by Barrow \& Feltham (1993). Growth on Slanetz-Bartley agar (Oxoid) and kanamycin aesculin azide agar (Merck) was tested. The 
reaction in litmus milk (Difco) was investigated after incubating cultures for 3,7 and 14 days. The effects of temperature $\left(10-45^{\circ} \mathrm{C}\right)$, starting $\mathrm{pH}(4.0,4.5,5.0,7.5,9.0$ and 9.6) and $\mathrm{NaCl}$ concentration (2, 4, 6, 6.5, 8 and $10 \%$, $\mathrm{w} / \mathrm{v})$ were determined by examining growth in GYPsodium acetate-mineral salt broth. Vitamin requirements were examined using the method of Kihara \& Snell (1960) with modifications. The isomer of lactic acid was analysed enzymically (Okada et al., 1978). Fatty acid methyl esters were prepared as described by Ikemoto et al. (1978) and cellular fatty acid compositions were analysed by using GLC [model GC-14A (Shimadzu), equipped with a CBP1 (OV-1) type capillary column, $25 \mathrm{~m} \times 0.25 \mathrm{~mm}$ inside diameter, at $180-220{ }^{\circ} \mathrm{C}$ and a flame ionization detector]. Gas-liquid chromatograms were calculated by using the Chromatopac C-R 4A data-processor (Shimadzu). Quinones were extracted from freeze-dried cells and purified as described by Collins et al. (1977) and Collins
\& Jones (1979). The purified quinones were analysed by HPLC (Tamaoka et al., 1983).

DNA was isolated and purified using the method of Saito \& Miura (1963). The DNA base composition was determined using reversed-phase HPLC (Tamaoka \& Komagata, 1984). PCR amplification and sequencing of the 16S rRNA and $r p o A$ genes were performed as described by Lane (1991) and Naser et al. (2005), respectively. The sequences were assembled and compared with deposited type strain sequences available in GenBank/EMBL/DDBJ by using BioEdit version 7.0.1 (Hall, 1999) and CLUSTAL_X version 1.83 (Thompson et al., 1997). Phylogenetic trees were constructed based on the maximum-likelihood (Felsenstein, 1989) and the neighbour-joining (Saitou \& Nei, 1987) methods by using the program NJPlot (Perrière \& Gouy, 1996). Confidence values of branches of the phylogenetic trees were determined using bootstrap

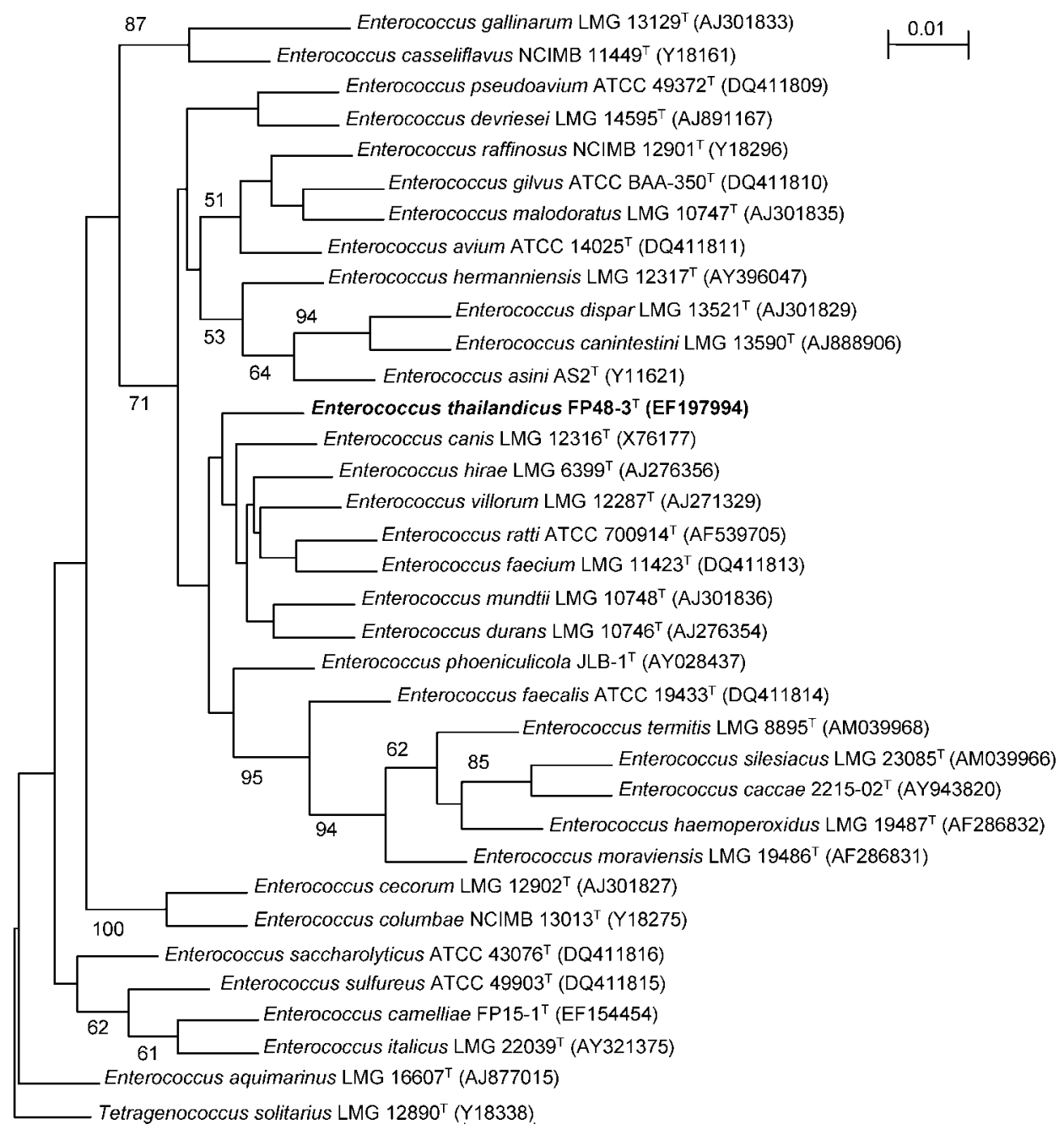

Fig. 1. Phylogenetic tree based on $16 \mathrm{~S}$ rRNA gene sequences, showing the relationships between strain FP48-3 ${ }^{\top}$ and related bacterial species. The branching pattern was generated by using the maximum-likelihood method. Based on 1000 replications, bootstrap percentages $\geqslant 51 \%$ are shown. Bar, 0.01 substitutions per nucleotide position. 
analysis (Felsenstein, 1985) based on 1000 resamplings. DNA-DNA hybridization experiments were performed as reported by Ezaki et al. (1989).

Cells of strain FP $48-3^{\mathrm{T}}$ were Gram-positive, facultatively anaerobic, non-motile, non-spore-forming, spherical or ovoid, and arranged in pairs or in chains. Detailed morphological, cultural, physiological and biochemical properties, including chemotaxonomic characteristics, are given in the species description. Menaquinones were not detected. Strain FP48 $-3^{\mathrm{T}}$ contained the straight-chain fatty acids $\mathrm{C}_{18: 1}(45.9 \%)$ and $\mathrm{C}_{16: 0}(25.7 \%)$ as the dominant components. The remainder of the fatty acids profile consisted of $\mathrm{C}_{14: 1}(1.2 \%), \mathrm{C}_{14: 0}(10.1 \%), \mathrm{C}_{16: 1}(13.3 \%)$, a trace amount of $\mathrm{C}_{18: 0}$ and unidentified components $(2.4 \%)$. Strain FP $48-3^{\mathrm{T}}$ contained roughly the same fatty acid pattern as its closest relative, E. hirae LMG $6399^{\mathrm{T}}$. The fatty acid $\mathrm{C}_{20: 1}$ and cyclopropane acids $\mathrm{C}_{17}$ and $\mathrm{C}_{19}$ were not detected in strain $\mathrm{FP} 48-3^{\mathrm{T}}$, but were present in E. hirae LMG $6399^{\mathrm{T}}$. The DNA G + C content of strain FP48-3 ${ }^{\mathrm{T}}$ was $37.9 \mathrm{~mol} \%$. The almost-complete $16 \mathrm{~S}$ rRNA gene sequence (1326 bp) of strain FP48- $3^{\mathrm{T}}$ indicated that the strain belonged to the genus Enterococcus and was closely related to E. hirae LMG $6399^{\mathrm{T}}$ (99.6\%), E. durans LMG $10746^{\mathrm{T}}$ $(99.6 \%)$ and E. faecium LMG $11423^{\mathrm{T}}$ (99.3\%). Lower sequence similarities $(<98.7 \%)$ were found with other recognized species of the genus Enterococcus (Fig. 1). A tree based on 16S rRNA gene sequences, constructed using the neighbour-joining method, is available as Supplementary Fig. S1, in IJSEM Online. Strain FP48- $3^{\mathrm{T}}$ was included in the E. faecium species group that currently contains $E$. faecium, E. hirae, E. durans, E. mundtii, E. villorum, E. ratti and E. canis (Collins et al., 1984, 1986; Farrow \& Collins, 1985; Vancanneyt et al., 2001; Teixeira et al., 2001; De Graef et al., 2003). The rpoA gene sequence ( $615 \mathrm{bp}$ ) of strain $\mathrm{FP} 48-3^{\mathrm{T}}$ showed $96.9,95.6$ and $95.1 \%$ similarity to E. faecium LMG $11423^{\mathrm{T}}$, E. durans LMG $10746^{\mathrm{T}}$ and E. hirae LMG $6399^{\mathrm{T}}$, respectively (Fig. 2). A tree constructed using the neighbour-joining method is available as Supplementary Fig. S2, in IJSEM Online. The application of multilocus sequence analysis for rapid identification of Enterococcus species based on the rpoA gene (Naser et al., $2005,2006)$, confirmed the separation of strain FP48-3 ${ }^{\mathrm{T}}$ from related species. Strain FP48-3 ${ }^{\mathrm{T}}$ showed low

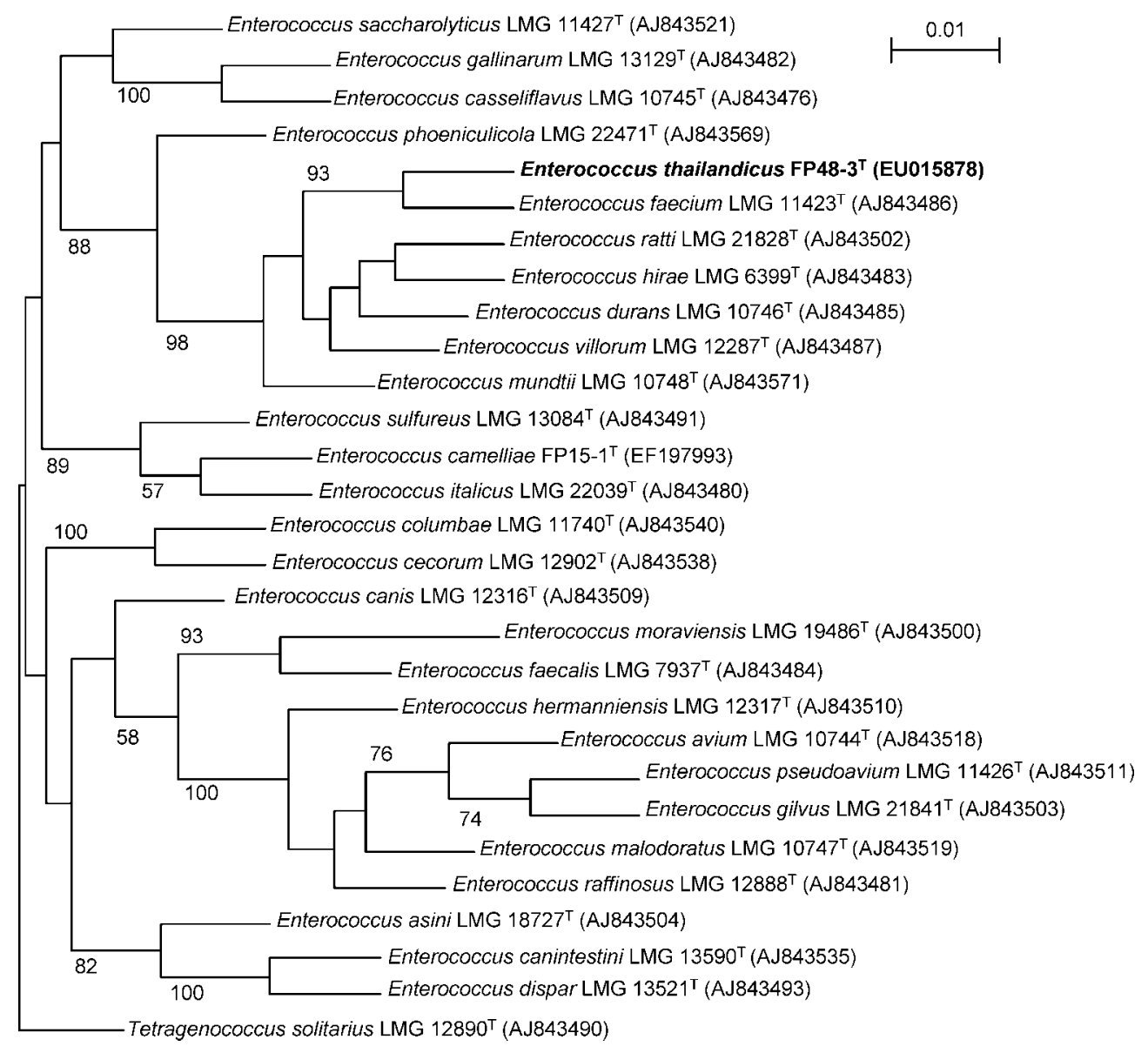

Fig. 2. Phylogenetic tree based on $r p o A$ gene sequences, showing the relationships between strain $\mathrm{FP} 48-3^{\top}$ and related bacterial species. The branching pattern was generated by using the maximum maximum-likelihood method. Based on 1000 replications, bootstrap percentages $\geqslant 57 \%$ are shown. Bar, 0.01 substitutions per nucleotide position. 
DNA-DNA relatedness to E. hirae LMG $6399^{\mathrm{T}}$ (6\%), E. durans LMG $10746^{\mathrm{T}}$ (7\%), E. faecium LMG $11423^{\mathrm{T}}$ (14\%) and E. mundtii LMG $10748^{\mathrm{T}}(6 \%)$. In addition, strain FP48- $3^{\mathrm{T}}$ could be differentiated from closely related Enterococcus species by growth at $\mathrm{pH} 5$ and no growth at $10{ }^{\circ} \mathrm{C}$, acid production and DNA G $+\mathrm{C}$ content, as shown in Table 1. Therefore, strain FP48-3 $3^{\mathrm{T}}$ should be classified in the genus Enterococcus as representing a novel species, Enterococcus thailandicus sp. nov.

\section{Description of Enterococcus thailandicus sp. nov.}

Enterococcus thailandicus (tha.i.lan'di.cus. N.L. masc. adj. thailandicus of Thailand, pertaining to Thailand, where the type strain was isolated).

Cells are Gram-positive, facultatively anaerobic, nonmotile, non-spore-forming, spherical or ovoid, $0.5-1 \mu \mathrm{m}$ in diameter and arranged in pairs or in chains. Colonies on GYP agar are circular, raised or low-convex with entire margins, and non-pigmented. Red colonies appear on Slanetz-Bartley agar. Grows on kanamycin aesculin azide agar. Positive for hydrolysis of arginine and aesculin, and weakly positive for blood haemolysis. Negative for catalase, hydrolysis of gelatin and starch, reduction of nitrate, and production of gas from glucose, gluconate and citrate. Utilizes glucose fermentatively. No acidification, coagulation, reduction or liquefaction in litmus milk. Grows at pH 5.0-9.6, $15-45{ }^{\circ} \mathrm{C}$ and in $2-6.5 \% \mathrm{NaCl}$. Weak growth occurs in $8 \% \mathrm{NaCl}$. Acid is produced from D-amygdalin, arbutin, cellobiose, dulcitol, fructose, D-galactose, $\beta$ gentiobiose, gluconate, D-glucose, glycerol, $N$-acetylglucosamine, lactose, maltose, D-mannose, methyl $\alpha$-D-mannoside, D-mannitol, D-ribose, sucrose and salicin but not from adonitol, D-arabinose, L-arabinose, D-arabitol, Larabitol, erythritol, D-fucose, L-fucose, 2-ketogluconate,

Table 1. Differential characteristics of strain $F P 48-3^{\top}$ (E. thailandicus sp. nov.) and related Enterococcus species

Strains: 1, FP48-3 $3^{\mathrm{T}} ; 2$, E. hirae LMG $6399^{\mathrm{T}} ; 3$, E. durans LMG $10746^{\mathrm{T}}$; 4, E. faecium LMG $11423^{\mathrm{T}}$. +, Positive; -, negative.

\begin{tabular}{|lcccc|}
\hline Characteristic & $\mathbf{1}$ & $\mathbf{2}$ & $\mathbf{3}$ & $\mathbf{4}$ \\
\hline Growth at: & & & & \\
pH 5.0 & + & - & $+^{*}$ & + \\
$10{ }^{\circ} \mathrm{C}$ & - & + & $+^{*}$ & + \\
Acid production from: & & & & \\
D-Galactose & + & - & + & + \\
Gluconate & + & - & - & + \\
Glycerol & + & - & - & + \\
D-Mannitol & + & + & - & + \\
Melibiose & - & + & - & - \\
Salicin & + & - & + & + \\
D-Sorbitol & - & + & - & - \\
DNA G+C content $(\mathrm{mol} \%)$ & 37.9 & 38.0 & 38.6 & 39.0 \\
& & & & \\
\hline
\end{tabular}

${ }^{\star}$ Data from Cai et al. (1999). 5-ketogluconate, methyl $\alpha$-D-glucoside, glycogen, inositol, inulin, D-lyxose, melezitose, melibiose, rhamnose, Lsorbose, starch, turanose, D-tagatose, D-sorbitol, raffinose, trehalose, xylitol, D-xylose, L-xylose or methyl $\beta$-xyloside. Niacin, calcium pantothenate and folic acid are required for growth. Does not contain any menaquinones. The dominant component of the fatty acid profile is the straight-chain acid $\mathrm{C}_{18: 1}$. The DNA $\mathrm{G}+\mathrm{C}$ content of the type strain is $37.9 \mathrm{~mol} \%$.

The type strain, $\mathrm{FP} 48-3^{\mathrm{T}} \quad\left(=\mathrm{KCTC} \quad 13134^{\mathrm{T}}=\mathrm{NBRC}\right.$ $101867^{\mathrm{T}}=$ NRIC $0107^{\mathrm{T}}=$ TISTR $933^{\mathrm{T}}=$ PCU $\left.282^{\mathrm{T}}\right)$, was isolated from fermented sausage ('mum'), produced in Thailand.

\section{Acknowledgements}

This study was supported by the Thailand Research Fund for a 2003 Royal Golden Jubilee Scholarship as a research grant to S. S. and in part by a grant from the KRIBB Research Initiative Program.

\section{References}

Baele, M., Baele, P., Vaneechoutte, M., Storms, V., Butaye, P., Devriese, L. A., Verschraegen, G., Gillis, M. \& Haesebrouck, F. (2000). Application of tRNA intergenic spacer PCR for identification of Enterococcus species. J Clin Microbiol 38, 4201-4207.

Barrow, G. I. \& Feltham, R. K. A. (1993). Cowan and Steel's Manual for the Identification of Medical Bacteria, 3rd edn, pp. 331. Cambridge: Cambridge University Press.

Cai, Y., Suyanandana, P., Saman, P. \& Benno, Y. (1999). Classification and characterization of lactic acid bacteria isolated from the intestines of common carp and freshwater prawns. J Gen Appl Microbiol 45, 177-184.

Collins, M. D. \& Jones, D. (1979). The distribution of isoprenoid quinones in streptococci of serological groups D and N.J Gen Microbiol 114, 27-33.

Collins, M. D., Pirouz, T., Goodfellow, M. \& Minnikin, D. E. (1977). Distribution of menaquinones in actinomycetes and corynebacteria. J Gen Microbiol 100, 221-230.

Collins, M. D., Jones, D., Farrow, J. A. E., Kilpper-Bälz, R. \& Schleifer, K. H. (1984). Enterococcus avium nom. rev., comb. nov.; E. casseliflavus nom. rev., comb. nov.; E. durans nom. rev., comb. nov.; E. gallinarum comb. nov.; and E. malodoratus sp. nov. Int J Syst Bacteriol 34, 220-223.

Collins, M. D., Farrow, J. A. E. \& Jones, D. (1986). Enterococcus mundtii sp. nov. Int J Syst Bacteriol 36, 8-12.

De Graef, E. M., Devriese, L. A., Vancanneyt, M., Baele, M., Collins, M. D., Lefebvre, K., Swings, J. \& Haesbrouck, F. (2003). Description of Enterococcus canis sp. nov. from dogs and reclassification of Enterococcus porcinus Teixeira et al. 2001 as a later synonym of Enterococcus villorum Vancanneyt et al. Int J Syst Evol Microbiol 53, 1069-1074.

Euzéby, J. P. (1997). List of bacterial names with standing in nomenclature: a folder available on the Internet. Int J Syst Bacteriol 47, 590-592.

Ezaki, T., Hashimoto, Y. \& Yabuuchi, E. (1989). Fluorometric deoxyribonucleic acid-deoxyribonucleic acid hybridization in microdilution wells as an alternative to membrane filter hybridization in which radioisotopes are used to determine genetic relatedness among bacterial strains. Int J Syst Bacteriol 39, 224-229. 
Farrow, J. A. E. \& Collins, M. D. (1985). Enterococcus hirae, a new species that includes amino acid assay strain NCDO 1258 and strains causing growth depression in young chickens. Int J Syst Bacteriol 35, 73-75.

Felsenstein, J. (1985). Confidence limits on phylogenies: an approach using the bootstrap. Evolution 39, 783-791.

Felsenstein, J. (1989). PHYLIP - phylogeny inference package (version 3.2). Cladistics 5, 164-166.

Hall, T. A. (1999). BioEdit: a user-friendly biological sequence alignment editor and analysis program for Windows 95/98/NT. Nucleic Acids Symp Ser 41, 95-98.

Hardie, J. M. \& Whiley, R. A. (1997). Classification and overview of the genera Streptococcus and Enterococcus. J Appl Microbiol 83 (Suppl.), 1S-11S.

Hucker, G. J. \& Conn, H. J. (1923). Method of Gram staining. N Y St Agric Exp Sta Tech Bull 93, 3-37.

Ikemoto, S., Katoh, K. \& Komagata, K. (1978). Cellular fatty acid composition in methanol-utilizing bacteria. J Gen Appl Microbiol 24, 41-49.

Kihara, H. \& Snell, E. E. (1960). Peptides and bacterial growth. J Biol Chem 235, 1409-1414.

Knudtson, L. M. \& Hartman, P. A. (1992). Routine procedures for isolation and identification of enterococci and faecal streptococci. Appl Environ Microbiol 58, 3027-3031.

Lane, D. J. (1991). 16S/23S rRNA sequencing. In Nucleic Acid Techniques in Bacterial Systematics, pp. 115-175. Edited by E. Stackebrandt \& M. Goodfellow. Chichester: Wiley.

Merquior, V. L. C., Peralta, J. M., Facklam, R. R. \& Teixeira, L. M. (1994). Analysis of electrophoretic whole-cell protein profiles as a tool for characterization of Enterococcus species. Curr Microbiol 28, 149-153.

Naser, S. M., Thompson, F. L., Hoste, B., Gevers, D., Dawyndt, P., Vancanneyt, M. \& Swings, J. (2005). Application of multilocus sequence analysis (MLSA) for rapid identification of Enterococcus species based on rpoA and pheS genes. Microbiology 151, 2141-2150.

Naser, S. M., Vancanneyt, M., Hoste, B., Snauwaert, C., Vandemeulebroecke, K. \& Swings, J. (2006). Reclassification of Enterococcus flavescens Pompei et al. 1992 as a later synonym of Enterococcus casseliflavus (ex Vaughan et al. 1979) Collins et al. 1984 and Enterococcus saccharominimus Vancanneyt et al. 2004 as a later synonym of Enterococcus italicus Fortina et al. 2004. Int J Syst Evol Microbiol 56, 413-416.
Okada, S., Toyoda, T. \& Kozaki, M. (1978). An easy method for the determination of the optical types of lactic acid produced by lactic acid bacteria. Agric Biol Chem 42, 1781-1783.

Perrière, G. \& Gouy, M. (1996). WWW-Query: an on-line retrieval system for biological sequence banks. Biochimie 78, 364-369.

Saito, H. \& Miura, K. (1963). Preparation of transforming deoxyribonucleic acid by phenol treatment. Biochim Biophys Acta 72, 619-629.

Saitou, N. \& Nei, M. (1987). The neighbor-joining method: a new method for reconstructing phylogenetic trees. Mol Biol Evol 4, 406-425.

Sukontasing, S., Tanasupawat, S., Moonmangmee, S., Lee, J.-S. \& Suzuki, K. I. (2007). Enterococcus camelliae sp. nov., isolated from fermented tea leaves in Thailand. Int J Syst Evol Microbiol 57, 2151-2154.

Švec, P., Vancanneyt, M., Sedláček, I., Naser, S. M., Snauwaert, C., Lefebvre, K., Hoste, B. \& Swings, J. (2006). Enterococcus silesiacus sp. nov. and Enterococcus termitis sp. nov. Int J Syst Evol Microbiol 56, 577-581.

Tamaoka, J. \& Komagata, K. (1984). Determination of DNA base composition by reversed-phase high-performance liquid chromatography. FEMS Microbiol Lett 25, 125-128.

Tamaoka, J., Katayama-Fujimura, Y. \& Kuraishi, H. (1983). Analysis of bacterial menaquinone mixtures by high performance liquid chromatography. J Appl Bacteriol 54, 31-36.

Tanasupawat, S., Ezaki, T., Suzuki, K., Okada, S., Komagata, K. \& Kozaki, M. (1992). Characterization and identification of Lactobacillus pentosus and Lactobacillus plantarum strains from fermented foods in Thailand. J Gen Appl Microbiol 38, 121-134.

Teixeira, L. M., Carvaho, M. G., Espinola, M. M. B., Steigerwalt, A. G., Douglas, M. P., Brenner, D. J. \& Facklam, R. R. (2001). Enterococcus porcinus sp. nov. and Enterococcus ratti sp. nov., associated with enteric disorders in animals. Int J Syst Evol Microbiol 51, 1737-1743.

Thompson, J. D., Gibson, T. J., Plewniak, F., Jeanmougin, F. \& Higgins, D. G. (1997). The CLUSTAL_X windows interface: flexible strategies for multiple sequence alignment aided by quality analysis tools. Nucleic Acids Res 25, 4876-4882.

Vancanneyt, M., Snauwaert, C., Cleenwerck, I., Baele, M., Descheemaeker, P., Goossens, H., Pot, B., Vandamme, P., Swings, J. \& other authors (2001). Enterococcus villorum sp. nov., an enteroadherent bacterium associated with diarrhoea in piglets. Int J Syst Evol Microbiol 51, 393-400.

Whittenbury, R. (1963). The use of soft agar in the study of condition affecting the utilization of fermentable substrates by lactic acid bacteria. J Gen Microbiol 32, 375-384. 